\title{
Article
}

\section{Hunting, Wildlife Management and the Federal Hunting Act in Germany}

\author{
Tobias Zorn* and Yutaka Ishii*
}

\begin{abstract}
Forests are ecosystems with multiple basic functions, namely wood production and conservation of the environment, including the soil, water functions and so on. Forest Policy provides the interface between the natural and social sciences in forestry. Its interrelations include the needs for products and services and incorporates wildlife management. Wildlife management is closely related to forestry and should be coordinated and integrated with forest management. Past developments in forestry can be characterized as a change from forest exploitation to modified forest management, or a change from emphasizing the productive to incorporating different functions. Sustainable forest management and the development of overall land use policies was developed hundreds of years ago. In Germany, hunting played an important role in the development of an integrated forest management policy.

In Japan, multiple-use forestry is a basic concept in forest policy. Water conservation, wood production and soil protection are emphasized, but wildlife management does not seem so important in Japanese forest management. Recently, the extent of damage by game has been highlighted in Japan. In this light, this paper focuses on wildlife management activities and the hunting act in Germany, in an attempt to make a contribution to the development of a wildlife management system for Japan.
\end{abstract}

Keyword: hunting, game, hunting act, Germany

\section{A SHORT HISTORY OF HUNTING IN GERMANY AND ITS CURRENT PROBLEMS}

The interaction of wildlife/game and human beings forms the basis of wildlife management. Hunting practices depend on social and legal realities. In Germany, the history of hunting is much longer than the two hundred-year -old history of sustainable forest management.

In the 17th and 18th centuries, Germany was ruled by kings and sovereigns. Each had his own opinion on hunting management and a few were energetic hunters. Roe deer was the preferred game species for all the sovereigns, and could only be hunted by the sovereign and his guests. Game species which were not of interest to the sovereign were hunted by professional hunters and foresters. Historical and socio-political circumstances influenced the hunting

* Department of Forest Science, Faculty of Agriculture, University of Hokkaido, Nishi 9, Kita 9, Kita-ku, Sapporo 060, Japan. and wildlife management of these times.

In this time of kings, sovereigns and nobility, farmers had no legal rights. Farmers had difficult lives and sometimes were pushed to the edge of survival. Damage by game to forests and farmland had to be accepted as a "normal" process which provided the nobility with the pleasure of hunting. Game species were regarded as "things" - "things" with which anyone could do whatever he wanted. The quality and quantity game populations were the most important considerations. Regulations went as far as restricting the population to their private sphere, so as to exclude people from the forests at certain times, or to restrict them to paths in order not to disturb the game. The restrictions were so severe that farmers had to accept that game fed on farm crops and heavily damaged or completely destroyed the farmland area (SCHWENK 1993).

Every hunter should behave according to the principles of hunting. Hunting ethics and the environmental acceptability of the aims and methods of hunting are now critical to the future of hunting (SCHWENK 1993). The 
relationships between humans and animals has changed through time and differs between cultures. Two hundred years ago, wildlife management in Germany aimed to provide enough game for the nobility to hunt.

Extensive post-colonial clearing and heavy settlement in combination with the development of infrastructure, such as streets and regulated waterways, changed the local environment, with many consequences for natural biotopes. The human impact on wildlife has been unquestionably high.

During the Second World War, for example, only a modest number of roe deer were hunted by German citizens (SCHWENK 1993). Between 1940 and 1950 political and social problems were being faced and hunting was limited to guest hunters, a few professional hunters and foresters. By comparison, during the period of occupation (19451951), a great number of roe deer were killed by soldiers of the occupation forces. This illustrates how political circumstances can influence hunting practices, even in modern times.

In Germany, the forests are the main habitat for wildlife and game. However, high game populations cause substantial damage in the forests. Over the last decade, there has been a change in forest management guidelines. The new guidelines promote gradually replacing clearfelling systems by selection systems, which allow regeneration under the shelter of large trees. This change was introduced because it was considered to be a closer representation of the natural system and it was expected to reduce browsing damage. Ecologically sensitive systems such as alpine forests suffer from overpopulation by cloven -hoofed game (LinN 1991). Species, such as fir (Abies alba), beech (Fagus sylvatica), maple (Acer pseudoplatanus) and ash (Fraxinus excelsior) are important for the regeneration of these mixed natural forests $(\mathrm{KECH}$ and EISFELD 1991).

According to investigations carried out during the national forest inventory of 1986-1990, high percentages of exposed young trees showed effects of overbrowsing. Firs and deciduous tree species were most affected (BUNDEsMINISTERIUM 1994). A state- wide evaluation of browsing in Bavaria in 1986 showed that large animals had a strong influence on regeneration: on average, $57 \%$ of all plants over $20 \mathrm{~cm}$ were browsed in the upper third of the plant and $36 \%$ were browsed at the terminal bud. In ten percent of spruce stands, bark damage by red deer was recorded (BAVARIAN State Government 1989). In forests with large populations of roe deer (Capreolus capreolus L.), overgrazing prevented natural regeneration of trees and the ground flora was extremely poor. There was a significant correlation between forest decline and game damage. The large population of roe deer was the result of mismanagement caused by a poor understanding of the population dynamics and the ecological requirements of the species
(Roucher et al. 1991). Browsing damage impedes the development of mixed forests (BAVARIAN STATE GOVERN ment 1989, Bundesministerium 1994, Federal Ministry of Agriculture AND Forestry 1990).

The interests of other parties, such as foresters, hunters, wildlife conservationists, nature and wildlife photographers and recreationists also influence wildlife management. The different interests of these groups sometimes provoke conflicts which can result in the deterioration of their relationships. However, all interest groups can make constructive contributions to wildlife management (LINN 1991). Wildlife management professionals, such as hunters and foresters, should understand how the animal populations will develop, and know how to maintain the quality of the environment. To maintain a suitable environment it is important that wildlife managers deal with the elementary ideas and fundamental relationships between the species and its environment (NyLAND et al. 1983). Hunting can help keep wild animal populations in balance with the resources of the habitat.

Farmers and forest owners suffer considerable economic losses from the grazing of planted trees and agricultural crops by wild animals. These individuals also incur additional costs, such as fencing and replanting of failed areas, as a result of browsing by wildlife.

Highly cultivated, monocultured and industrialized landscapes have become secondary biotopes for autochthonous wildlife species (Gossow 1991). The historical view is that wildlife management and forest science are closely connected and that they are important socio-politically. This view has arisen from the interactions between hunters and the animals, between hunters and the environment, and between hunters and society (ScHWENK 1993).

\section{WILDLIFE, GAME AND HABITAT MANAGEMENT}

Most people no longer depend upon wild animals for food supply or meat production, although in rural and remote areas of Germany hunting does provide supplementary food for the local population. Since the domestication of animals such as cattles, pigs, chicken, and changes in eating habits, game species such as deer, hare and wild boar have become delicacies. Wildlife also provide noncommercial benefits, but it is difficult to assign a specific monetary value to wildlife. The non-commercial benefits of wildlife include a psychological and aesthetic value, and an improved environment (NyLAND et al. 1983).

Hunting of a number of species of animals is permitted in Germany, including 25 fur animals and 22 feather animals. Table 1 shows the most commonly hunted animal species. ${ }^{1}$ 
Table 1 Hunted species statistics (new Federal States and former territory of the Federal States)

\begin{tabular}{lrrrrrrrr}
\hline \multicolumn{1}{c}{ species } & $1990 / 91$ & $1991 / 92$ & $1992 / 93$ & $1993 / 94$ & $1990 / 91$ & $1991 / 92$ & $1992 / 93$ & $1993 / 94$ \\
\hline former territory & of the Federal States & & & new Federal States & \\
red deer & 31,089 & 29,517 & 30,243 & 33,320 & 32,461 & 28,870 & 29,117 & 29,255 \\
fallow deer & 15,148 & 15,576 & 15,544 & 17,250 & 19,761 & 19,559 & 20,685 & 21,985 \\
moufflon & 2,179 & 2,052 & 2,247 & 2,533 & 4,080 & 3,581 & 4,348 & 4,658 \\
wild-boar & 152,315 & 175,469 & 106,117 & 192,164 & 153,425 & 137,299 & 142,719 & 147,068 \\
roe-deer & 781,263 & 801,840 & 785,481 & 804,245 & 144,332 & 150,556 & 200,602 & 106,106 \\
hare & 593,426 & 511,782 & 548,414 & 531,930 & & & & \\
rabbit & 846,548 & 720,487 & 756,085 & 700,112 & & & & \\
pheasant & 362,892 & 278,286 & 389,660 & 342,213 & & & & \\
partridge & 29,328 & 18,283 & 21,453 & 24,527 & & & & \\
duck & 559,726 & 528,930 & 530,473 & 481,400 & & & & \\
pigeon & 772,241 & 916,549 & 809,793 & 757,471 & & & & \\
fox & 319,457 & 298,924 & 340,686 & 428,941 & & & & \\
marten & 48,187 & 43,747 & 42,440 & 42,163 & & & & \\
\hline
\end{tabular}

Source: Deutscher Jagdschutz-Verband, in: Statistisches Bundesamt 1995

The species hunted can be divided into two groups: big game, and small game.

Big game includes cloven-hoofed game, such as European bison, moose, red deer, fallow deer, sika deer, chamois, ibex, moufflon and wild-boar, with the exception of roe -deer; in addition, eagles are also included in big game. All other game is classified as small game (BUNDESMINISTER IUM 1985).

The most common game species in Germany are: red deer (Cervus elaphus L.), fallow deer (Dama dama L.), roe-deer (Capreolus capreolus L.), moufflon (Ovis ammon musimon PALlas), wild-boar (Sus scrofa L.), brown hare (Lepus europaeus PALLAS), rabbit (Oryctolagus coniculus L.), fox (Vulpes vulpes L.), and beech marten (Martes foina ERXLEBEN) for fur game species, and partridge (Perdix perdix L.), pheasant (Phasianus colchicus L.), dove and pigeon (Columbidae), and wild-duck (Anatinae) for feather game species.

All wild animal species have a certain living-territory, called its habitat. The habitat satisfies the physical and biological requirements of the species and the highest state of productivity is provided if the animals and the habitat elements are in balance. A habitat with a good range of conditions satisfies the functional needs of most animals (NYLAND et al. 1983). In forests, the condition of the vegetation cover is a valuable indicator of the carrying capacity.

Diversity in the habitat, limits of suitable habitat, territorial behavior of the animals, and the overlapping of home ranges are all important elements in wildlife habitat. The carrying capacity of a habitat can be used to judge the balance between wild animal populations and area. The dynamics of wild animal populations are characterized by population increases and decreases over time. The balance and interactions between predators and prey varies with species and with the capacities of the ecosystem (NYLAND et al. 1983).

Seasons and the change in daylight hours have a great influence on wildlife. Animals migrate between winter, spring, summer and autumn to cope with changes in the climate and vegetation. The migration can be over long or short distances depending on the species. Unfortunately, due to the anthropogenic influence of feeding game animals and destruction of habitat units, some animals lose their migration instinct. For example, red deer use different habitats in different seasons, although historically the differences were much clearer and characterized by migrations. In summer the deer moved to high elevations in the mountains, and during winter they migrated to lower areas. The migration avoided a concentration of animals in one place.

Wild boars (Sus domestica) also prefer different biotopes from season to season. From February to April they mostly root in coniferous forests and from August they feed more intensively in deciduous forests (SzCZEGOLA 1991). Special attention has to be paid to the wild boars on account of the damage they cause in fields and forests. Although the damage in forests is less than in fields (KoHALmy 1991), they unquestionably exist. 


\section{HUNTING ACT}

Hunting Rights

According to Germanys Hunting Act, people with the right to hunt shall care for, protect and hunt those animals living in a wild state and which are allowed to be hunted on a specified area of land. People with the right to hunt are also obliged to care for and protect game (BUNDESMINIS TERIUM 1985). Forest owners, hunting cooperations, the owners of hunting rights, as well as the hunting authorities, are the executive organs for hunting (BAVARIAN STATE GOVERNMENT 1989).

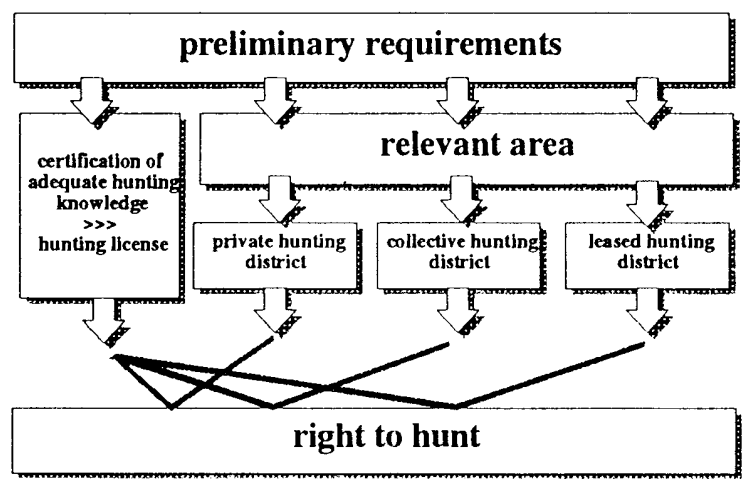

Fig. 1 Preliminary requirements, which lead to the right to hunt
As Figure 1 shows, the hunting license and access to a hunting district are the two preliminary requirements for hunting.

A considerable number of professional hunters and hunting guests and a lesser number of hunting rights controlled by the state provide the foundation for wildlife management in Germany. The number of hunters and hunting areas in Germany is shown in the following table (Table 2)

Landowners are entitled to hunting rights on their own estate. On land for which there is no established ownership, the right to hunt belongs to the States, but hunting can only be practiced in specially designated hunting districts (BUNDESMINISTERIUM 1985)

\section{Hunting Districts}

Hunting districts in which hunting can be practiced are either "estate owners private hunting districts" or "collective hunting districts". These two categories comprise almost $90 \%$ of all hunting districts, as Table 3 clarifies.

Hunting districts are not only agricultural and forested areas, but may include natural and artificial watercourses, roads, railway installations and similar areas which do not constitute separate hunting districts in themselves. A district should be continuous and represent one area, with a link to other areas to keep a balance between other hunting districts. Private hunting districts form con-

Table 2 Number of hunters and hunting area in Germany

\begin{tabular}{lrrrr}
\hline \multicolumn{1}{c}{ state } & \multicolumn{3}{c}{$\begin{array}{c}\text { Hunters } \\
\text { (number of persons) }\end{array}$} & $\begin{array}{c}\text { Hunting Area } \\
\text { (in 1,000ha) }\end{array}$ \\
\hline & \multicolumn{1}{c}{1980} & 1990 & 1994 & 1994 \\
\cline { 2 - 5 } Germany & 296,477 & 317,257 & 325,767 & 32,082 \\
\hline Baden-Württemberg & 29,211 & 31,400 & 31,258 & 3,349 \\
Bayern & 46,087 & 48,362 & 50,377 & 6,800 \\
Berlin & & 1,201 & 2,126 & 19 \\
Brandenburg & & 11,000 & 12,000 & 2,269 \\
Bremen & 1,308 & 1,304 & 1,260 & 21 \\
Hamburg & 3,301 & 2,749 & 2,849 & 39 \\
Hessen & 18,482 & 20,840 & 20,793 & 1,787 \\
Mecklenburg-Vorpommern & & 9,500 & 9,500 & 1,908 \\
Niedersachsen & 52,204 & 56,179 & 56,126 & 4,250 \\
Nordrhein-Westfalen & 70,155 & 74,000 & 76,132 & 3,301 \\
Rheinland-Pfalz & 15,948 & 16,555 & 16,959 & 1,980 \\
Saarland & 3,327 & 3,454 & 3,631 & 246 \\
Sachsen & & 7,200 & 7,346 & 1,430 \\
Sachsen-Anhalt & & 9,000 & 8,617 & 1,900 \\
Schleswig-Holstein & 16,454 & 16,013 & 18,195 & 1,457 \\
Thüringen & & 8,500 & 8,598 & 1,327 \\
\hline Source: Deutscher Jagdsh & & &
\end{tabular}

Source: Deutscher Jagdschutz-Verband, in: Statistisches Bundesamt 1995 
Table 3 Hunting districts of the states, the estate owners private and collective

\begin{tabular}{|c|c|c|c|c|c|c|c|c|}
\hline & \multicolumn{2}{|c|}{1987} & \multicolumn{2}{|c|}{1988} & \multicolumn{2}{|c|}{1989} & \multicolumn{2}{|c|}{1990} \\
\hline & mill. ha & in $\%$ & mill. ha & in $\%$ & mill. ha & in $\%$ & mill. ha & in $\%$ \\
\hline $\begin{array}{l}\text { hunting districts of the states } \\
\text { and the country }\end{array}$ & 2.36 & 10 & 2.36 & 10 & 2.34 & 10 & 2.31 & 10 \\
\hline $\begin{array}{l}\text { estate owners private hunting } \\
\text { district and collective hunting } \\
\text { districts }\end{array}$ & 21.21 & 90 & 23.57 & 90 & 21.2 & 90 & 20.9 & 90 \\
\hline total hunting districts & 23.57 & 100 & 23.57 & 100 & 54 & 100 & 23.21 & 100 \\
\hline
\end{tabular}

tinuous stretches of land of at least 75 hectares, and are the property of one person. Because of the geographical and topographical conditions, the minimum size of private hunting districts in alpine regions is larger. To satisfy the criteria for a private hunting district, the land should be contiguous, and not interrupted by natural or man-made boundaries. Private hunting districts extending over more than one state are subject to the legal provisions of each state within which it lies (BUNDESMINISTERIUM 1985). Collective hunting districts are formed by a continuous stretch of land of at least 150 hectares. They include all land holdings which do not belong to private hunting districts. A collective hunting district can be divided into several independent hunting districts, if each "under-district" has a minimum size of 250 hectares. In the case of a private hunting district, the owner has the right to hunt. In the case of a collective hunting districts the hunting syndicate has the right to hunt. All the individual land owners, within the collective hunting district constitute the hunting syndicate, which allows judicial representation. The hunting syndicate is elected by the members of the collective hunting district.

\section{Hunting Leases}

If the landowner does not have a personal interest in hunting, he can lease his right to hunt, in its entirety, to a third party, or he may reserve for himself a part of the hunting rights on his own property. Leased hunting districts must be at least the same size as a private hunting district or at least 250 hectares in the case of collective hunting districts (BUNDESMINISTERIUM 1985).

The hunting lease is drawn up as a written contract for at least nine years. A lessee can only be a person with an annual hunting license which they have possessed for at least three years, and which was issued by the competent authority. The license must be carried when hunting and shown on request to officially empowered persons for control. The competent authority has to be notified of any hunting leases.

\section{Hunting License}

The hunting license is a document issued yearly which permits hunting. It must be renewed each year. A temporary hunting license can be issued for fourteen consecutive days. To obtain a license, a hunter must pass an examination consisting of a written, an oral and a practical section, a shooting test. Hunters are tested for an adequate knowledge of animal species, the biology of game animals, game conservation, game management and hunting, the prevention of game damage, agriculture and silviculture, weapon regulations, weapon techniques, the handling of weapons (including hand fire-arms), the handling of hounds, the treatment of game once it is killed with special reference to hygiene measures, the use of game meat as food, and the laws on game and animal protection, nature conservation and the maintenance and care of natural amenities.

A hunting license for minors, who have completed their sixteenth year but are not yet eighteen years old, can be issued with special conditions. These persons are not allowed to hunt in large hunting or game driving parties, and must hunt in the presence of an experienced supervisor.

To receive a hunting license, a hunter must provide assurance that they are trustworthy and physically able to handle weapons. Persons who cannot provide such assurance or from whom the hunting license has been withdrawn may not receive the right to hunt.

Additionally, hunters must have adequate hunting liability insurance ( 1 million German Marks for personal injury and 100000 German Marks for damage to property). This insurance may be taken out only with an insurance company which is authorized to handle hunting liability insurance within the jurisdiction of the Law on the Supervision of Private Insurance Companies (Bundes. MINISTERIUM 1985).

The Federal Hunting Law listed other reasons to refuse a hunting license, including the following items: "...

1. persons who are not yet eighteen years old; 
2. persons who are not German nationals within the meaning of Article 116 of the Basic Law (i.e. the Provisional Constitution of the Federal Republic of Germany); 3. persons who have not been resident or habitually domiciled within the jurisdiction of the Federal Forest Act for at least three years;

4. persons who have gravely or repeatedly violated the regulations.

5. persons who have wrongfully or irresponsibly used weapons or ammunition;

6. persons who handle weapons or ammunition without due caution and will not take care to hold these objects in safe keeping;

7. who are not entitled to have actual control over these objects (BUNDESMINISTERIUM 1985)

..."

If grounds for refusal of the hunting license become apparent after the hunting license has been issued, the issuing authority is obliged to declare the hunting license invalid and to confiscate it, without refunding the license fee. The authorities may also impose a ban on the reissue of the hunting license for a limited period (Bundesminis. TERIUM 1985).

\section{Restrictions on Hunting}

The Restrictions on Hunting are prohibitions, including weapons or techniques which are forbidden for hunting (BUNDESMINISTERIUM 1985), or obligations such as not disturbing game, not killing under conditions which are totally against the hunting ethic and not using supporting tools which make hunting easier.

For the benefit of the animals, it is important not to disturb game in its places of refuge, nesting, breeding or resting. Searching, photographing, filming or similar activities, are therefore prohibited, particularly if a species is endangered or threatened. Hunting in nature reserves, game reserves, national parks and wildlife-parks is controlled by the States.

The aim of wildlife management is to maintain the population of each game species and to protect those species which are threatened. Hunting can help regulate the population, and a quota defined by the competent authority and the hunting advisory council, specifies the number of cloven-hoofed game animals (with the exception of wildboars) which can be killed (BUNDESMINISTERIUM 1985).

In the Federal State of Germany, details are specified by legislation in the individual States. The States use a notification system to control and regulate the number of game hunted, so that the actual harvest can be compared and adjusted to meet the quota. The results, differentiated by game species and sex are published in hunting lists. For game species whose populations are out of balance or which seem to be threatened, hunting can be completely prohibited in specified districts or in specified hunting grounds, or the number of animals allowed to be killed can change. The numbers of game killed in state forests is regulated by the States.

In Germany, the hunting year is from April 1 to March 31 and is designated by the Federal Ministry with the consent of the Upper House of Parliament. Hunting seasons and closed seasons are regulated according to the biological timetable of wildlife development; however, the State may issue waivers in closed seasons for special reasons, such as the control of contagious diseases, avoidance of excessive game damage, for scientific, educational and research purposes, or if the equilibrium of the population is disrupted. The general use and development of land within each state is important too, so the States may fix hunting seasons in individual cases and permit exceptions (BUNDESMINISTERIUM 1985) .

Closed seasons enable the biological development of game species and protect the animals during the dropping and breeding seasons, until the young have become independent. Exceptions can be made, for example, for the wildboar, rabbit, fox or wood-pigeon, if damage to forests and croplands is expected.

Game and Hunting Damage

Game and hunting damage can be quite severe for other land owners and one of the duties of wildlife managers is to prevent game damage. Both the person entitled to hunt and the other land owner have a duty to prevent game damage, by keeping away or driving off game from endangered forests or agricultural cropland (BUNDESMINIS. TERIUM 1985).

To prevent excessive game damage, the game population must be reduced to a specified level within a specified period. These guidelines serve the public good, particularly to the interests of agriculture, forestry and the requirements of nature conservation and the maintenance and care of natural amenities. If the person entitled to hunt does not fulfill his duty, the competent authority may reduce the game population at his expense (BUNDESMINISTERIUM 1985).

Another restriction on game management is that wild -boars and rabbits may not be released into the wild. The practice of releasing wild or colonizing exotic animal species in open country is restricted or prohibited by the States, to avoid disrupting the ecosystem.

Game damage, on land belonging to a collective hunting district, must be paid for by the hunting syndicate. Each syndicate member pays in proportion to the area of land which he represents in the syndicate (BUNDESMINIS. TERIUM 1985).

Game damage on private hunting districts is paid for by the owner or the person who is in charge of the private hunting district. In the case of leasing, the lessee must take 
responsibility.

However, the farmers and foresters are also responsible for preventing damage to their crops or land. If the injured party has not rendered effective measures against game damage, compensation wont be paid. Under this regulation, compensation will not be paid for damage done to vineyard gardens, orchards, tree nurseries, tree-lined avenues, isolated trees, forest plantations, or outdoor horticultural or commercial plantings, if the customary protective devices, which under normal circumstances are sufficient to keep game away, have not been provided (Bundes. MINISTERIUM 1985).

Persons who practice hunting have a responsibility to do it in such a way that fields or forests wont be damaged or destroyed. Otherwise, they are liable to compensate for improper hunting practices resulting in damages.

The injured party must make a claim to the competent authority within one week of noticing the damage to his property. In the case of forestry, claims can be made twice a year, in May and October. The competent authority must be notified of the exact time and the person to be held liable for compensation. (BUNDESMINISTERIUM 1985).

\section{CONCLUSION}

The aim of including hunting in wildlife management is to use hunting as a tool to maintain the viability and stability of ecosystems. Changes in wildlife populations are an early-warning signal of changes in environmental quality (NyLAND et al. 1983). The loss of sensitive wild species gives early warning of environmental changes which may be due to exploitation and careless land use. Since different species react differently to environmental change, it is possible that the ecosystem can be continually degraded, or sustained. Management needs to monitor the habitat for species. Constant, annual monitoring provides an early warning to the condition of the wildlife ecosystems. Hunting regulations and wildlife management should preserve critical habitat and protect these species.

Knowledge about population dynamics is the foundation for wise decisions about wildlife management. From this base, decisions on active and passive measures can be made, and management plans can be implemented. A common tool is the inventory, for example, inventories of the forest cover vegetation conditions, or inventories of the population of a wild animal species, by direct counts of the individuals. The identification and observation of these animals gives excellent data. Analysis of the results allow the carrying capacity of the site to be determined and allows sustained yield management.

To get a good overview of population changes, these inventories must be repeated. A one time inventory only provides data about the status quo; to understand the dynamics, more than one inventory is necessary. Management programs must be based on the assessment of habitat elements and their extent, to determine the future planning and improve the conditions in the habitat to reach a naturally orientated habitat (NYLAND et al. 1983).

The state of the vegetation is an indicator of the game population. For that reason, the state of the vegetation, especially the regenerating vegetation, is used as an index of population density. Assessment of browsing damage to young trees and the state of the regeneration are the main items used to plan the annual game harvest in Germany (BAvarian State Government 1989). One method for getting information about roe deer density is to survey terminal shoot browsing. On sample plots, the browsing of terminal shoots within and outside of control fences is surveyed. Typically, the browsing pressure outside the fence is especially severe in deciduous trees and most damage occurs during the winter time (KECH and EISFELD 1991).

Measures for the prevention of damage by game were defined by the Bavarian State Government (1989). Combined techniques of technical and biological measures are installed. "...

- Regulating game density in the available natural habitat, - preservation and improvement of the game habitat by maintaining natural forests through:

* regenerating locally adapted mixed stands,

* using long-term regeneration,

* promoting fruit-bearing deciduous trees (oak, beech, wild fruit trees)

${ }^{*}$ preserving soft deciduous species (willow, aspen) which do not harm the development of stable new stands,

* leaving branches and twigs of felled trees on the ground, protecting young stands from browsing and bark peeling by fencing, and treatment of individual plants,

- planting of game feed and browsing areas,

providing species-oriented fodder for severe winter conditions,

establishing winter enclosures for red deer,

keeping and creating game refuge zones, e.g. by guiding recreational traffic and declaring game sanctuaries,

educating citizens to a better understanding and more responsible behavior towards nature, primarily in leisure sports. ,.."

Due to development, industrialization, and intensified human activities, biodiversity is decreasing. Mankind, and especially the hunter, become responsible for regulating wild animals. Man has taken over the role previously held by "natural disasters", "blowdowns", "insect infestations", "wildfires", and "predators". Hunting should be matched to ecological requirements. Unfortunately, the motivation of hunters is not always led by ecological aspects only, but also by the traditional thinking of hunting as the collection 
of trophies, an attitude which is still strong in the hunting world (Federal Ministry of Agriculture and Forestry 1990).

To achieve higher numbers of suitable wildlife species, structural biotope characteristics prove to be the most relevant measure of habitat suitability, possible species diversity and specific carrying capacity (Gossow 1991).

The diversity of habitats can be improved by increasing the width of edges between different forest communities; i.e. increasing the transition zone between one kind of land use and another, which increases the range of habitat conditions (NYLAND et al. 1983).

The discussion nowadays usually focuses on the arguments about:

- reintroducing the most dangerous predators (lynx, wolf) of the roe deer,

reducing the feeding of nutritive winter fodder (only if the winter conditions are very severe and the mortality would increase dramatically) and

- enlarging the size of hiding places, providing microhabitats.

To achieve the goal of high quality wildlife and hunting management, forest and wildlife managers have to work together. The concept of 'wise' or 'sustainable' use has become the principle of hunting management. Hunting cant be viewed as separate from agricultural, forestry and water management activities, as it is closely related to these activities. Hunting is a traditional use of nature and can be used as a method of managing wildlife populations (LINN 1991). Hunting also means respecting wildlife as a basic natural resource and understanding hunting as a rational use of wildlife, which implies taking responsibility for game management on certain areas. In the long run, since the ecosystem supposed to reach an equilibrium with a sustainable animal population, it should come back to its natural self-carrying equilibrium. The integration of hunting in forest management has to be improved. The rising demands for wildlife management in forestry have to be faced rigorously. Experience managing game species in Germany shows that not all species can be managed successfully under the same guidelines. It is therefore necessary to develop individual strategies for each game species. Furthermore, wildlife management must be integrated properly into forest management if it is to be successful. Reducing game populations to ecologically justifiable levels has become absolutely necessary (BAVARIAn STATE GOVERnMENT 1989, Bundesministerium 1994, FEDERAL Ministry of Agriculture And Forestry 1990). In the future, wildlife management must be based on forest territories and scientific and technical progress used to improve management methods. Hunting is part of the complicated network which includes socio-economics, forestry and game biology.
The following thoughts are the conclusions of our analysis of hunting, wildlife management and the Federal Hunting Act in Germany. These can make a valuable contribution to wildlife management in Japan.

1) Multiple-use forestry extends beyond the commercial function of wood production and the protective function of water resources, to include wildlife management, amongst other things. Wildlife management principles, including hunting regulations, should be incorporated in forest management.

2) Before critical stocking levels are reached, or browsing changes the tree species composition, wildlife management guidelines should be developed. These guidelines should be developed by both hunters and foresters in cooperation.

3) There is a need for an effective method of estimating game populations. The condition of the forest vegetation is a variable, which affects and is affected by the wildlife populations. A survey of the condition of the vegetation and the status of tree regeneration, so called 'vegetation expertise', could be a useful method for wildlife management for Japan.

4) The forest edge is a part of the forest, which is important for the wildlife. Highly structured forest edges of different tree species are valuable areas for grazing in times of need. Forest edges should be established to serve this purpose and help improve the landscape of both the forests and the agrarian areas.

5) Increasing outdoor activities in Japan may increase browsing and grazing pressure in particular forest areas. Strictly protected wildlife zones, where the human outdoor sports activities do not have any disturbing effect should be designated.

6) Fencing and other protective measures are very expensive, especially in extensive areas, such as Hokkaido. In these areas, population control, e.g. by hunting, may be the only effective means of regulating animal populations.

7) Wildlife management must become a part of forest training. Specifically, education at universities should include hunting and wildlife management as a theoretical component of forest science.

\section{LITERATURE CITED}

Bavarian State Golerniment, (1989) : The forest-environmental protection in Bavaria. A brochure from the Bavarian State Government, Munich, 36pp

Bundesministerium für Ernährung, Landwirtschaft und Forsten, (1985) : Bundesjagdgesetz. Bundesgesetzblatt I Seite 2849 vom 1. Oktober 1976, Bonn, 51pp

Bundesministerium für Ernährung, Landwirtschaft und Forsten, (1991) : Statistisches Jahrbuch über Ernährung, Landwirtschaft und Forsten der Bundesrepublik Deutschland. Landwirtschaftsverlag GMBH, Miinster-Hiltrup, 513pp 
Bundesministerium für Ernählong, Landwitschiaft und Forsten, (1994) : Nationaler Waldbericht der Bundesrepublik Deutschland. Bonn, 94pp

Federal Ministry of Agriculture and Forestry, (1990) : The forests of Austria. Vienna, 40pp

Gossow, H., (1991) : Habitat Evaluation Procedures (HEP) for ungulate game management in Central Europe - A constructive critique. Transactions of the XXth Congress of the International Union of Game Biologist. 1: 89

KeCir, G. and Ersfeeld, D., (1991) : Verbiss durch Rehwild (Capreolus capreolus) bei unterscheidlichen Dichten. Transactions of the XXth Congress of the International Union of Game Biologist. 1: 90-98

Kollalmy, T., (1991) : Assessment of wild boar stocks in Hungary. Transactions of the XXth Congress of the International Union of Game Biologist. 1: 99

Linn, S., (1991) : The C.I.C. Caprini Working Group. Transactions of the XXth Congress of the International Union of Game Biologist. 1: 131

Nyland, R.D., Larson, C. and Shirley, H.L., (1983) : Forestry and its career opportunities. McGraw-Hill Book Company, New York, 381 pp

Roucher, F., de Turckifin, B. and Peccoud, J., (1991) : Integrated management of roe deer and trees. Transactions of the XXth Congress of the International Union of Game Biologist. 1: 173-178

SCHWENK, S., (1993) : Hunting ethics and the sustainable use of nature - History and Strategy. Proceedings of the International Union of Game Biologists XXI Congress. 206-209

Statistiscies Bundesamt, (1995) : Statistisches Jahrbuch 1995. Metzler Poeschel Verlag, Wiesbaden, 771pp

Szczecola, M., (1991) : The intensity of rooting in different parts of forest habitat in the annual cycle. Transactions of the XXth Congress of the International Union of Game Biologist. 1: 195

\section{APPENDIX}

Content of the Hunting Act

Federal Hunting Act (Bundesministerium 1985 ) (Revised version of September 29, 1976, valid as from April 1, 1977)

\section{Part I The Right to Hunt}

Section 1: Substance of the Right to Hunt

Section 2: Species

Section 3: Holder of Hunting Rights; Exercise of the Right to Hunt

Part II Hunting Districts and Conservation Associations

1. General

Section 4: Hunting Districts

Section 5: The Shaping of Hunting Districts

Section 6: Districts Designated as Sanctuaries; Suspension of Hunting

2. Private Hutnting Districts

3. Collective Hunting Districts

Section 9: Hunting Syndicate

Section 10: Accruals from Hunting

4. Game Management Associations
Section 10 a: Formation of Game Management Associations

Part III Participation of third Parties; In the Exercise of Hunting Rights

Section 11: Hunting Lease

Section 12: Notification of Hunting Leases

Section 13: Lapse of the Hunting Lease

Section 13a: Legal Status of Joint Lessees

Section 14: Change of Landowner

Part IV Hunting License

Section 15: General

Section 16: Hunting License for Minors

Section 17: Refusal of the Hunting License

Section 18: Confiscation of a Hunting License

Part V Restrictions on Hunting, Obligations in the Practice of Hunting and Disturbance of Game

Section 19: Prohibitory Points

Section 19a: Disturbance of Game

Section 20: Locally Barred Hunting

Section 21: Regulation of Numbers Killed

Section 22: Hunting Seasons and Close Seasons

Section 22a: Prevention of Avoidable Pain or Suffering in Game

Part VI Game Protection

Section 23: Substance of Game Protection

Section 24: Contagious Diseases of Game

Section 25: Persons Empowered to Protect Game

Part VII Game and Hunting Damage

1. Prevention of Game Damage

Section 26: Fending off Game

Section 27: Prevention of Excessive Game Damage

Section 28: Other Restrictions on Game Management

2. Compensation for Game Damage

Section 29: Liability to Compensation for Game Damage

Section 30: Damage by Game from a Game Reserve

Section 31: Extent of the Liability to Compensation

Section 32: Protective Devices

3. Hunting Damage

Section 33: Liability to Compensation for Damages

4. Joint Provisions

Section 34: Assertion of Damages

Section 35: Procedure in Actions for Game and Hunting Damages

Part VIII Commercialization and Protection of Game

Section 36: Enabling Legislation

Part IX Hunting Advisory Council and Huntsmens Societies

Section 37 Hunting Advisory Council and Huntsmens Societies

Part X Provisions for Pains and Penalties

Section 38: Criminal Offenses

Section 39: Offenses against Police and Administrative Regulations Section 40: Confiscation

Section 41: Ordering Withdrawal of the Game License

Section 41a: Hunting Ban

Section 42: Provisions for Pains and Penalties by Individual States

Part X I Concluding Provisions

Section 43: Expire of Hunting Leases

(Received 15 November 1996)

(Accepted 9 January 1997) 